\title{
The Concept of "Kampus Merdeka" in Accordance with Freire's Critical Pedagogy
}

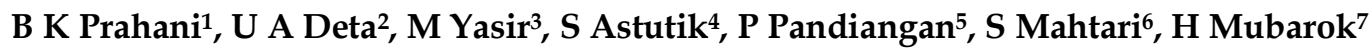 \\ 1,2Department of Physics, State University of Surabaya, Surabaya 60231, Indonesia \\ 3 Department of Science Education, University of Trunojoyo, Madura 69162, Indonesia \\ ${ }^{4}$ Department of Physics Education, Jember University, Jember 68121, Indonesia \\ 5Department of Physics Education, Indonesian Open University, Jakarta 15418, Indonesia \\ ${ }^{6}$ Department of Physics Education, University of Lambung Mangkurat, Banjarmasin 70123, Indonesia \\ ${ }^{7}$ Graduate Institute of Digital Learning and Education, NTUST, Taipei 10607, Taiwan
}

\section{Article Info \\ Article history: \\ Received March 01, 2020 \\ Revised March 21, 2020 \\ Accepted April 1, 2020 \\ Keywords: \\ Kampus Merdeka \\ Paulo Freire \\ Philosophy of Education}

\begin{abstract}
The Kampus Merdeka lately becomes the center of attention for the education circle in Indonesia. The government via Indonesian Minister of education and culture believed that the Kampus Merdeka as an effort to freedom for the education system more supportive of students and lecturers in achieving quality learning meaningful to face the disruption of the current era. This paper presents the author's views on "Kampus Merdeka" which was promoted by the Indonesian government. Also, the authors will underline the concept of "Kampus Merdeka" in accordance with Paulo Freire's critical pedagogy. In our point of view, we give a position this concept is developed based on the thinking of Paulo Freire. As we know, Freire's educational model offered a model of education for freedom. In this case, the term 'freedom' means a transformation in a real system that is competitively related and complex.
\end{abstract}

\section{INTRODUCTION}

Freedom to learn is a new policy program of the Ministry of Education and Culture (MOEC) of the Republic of Indonesia and it was launched by the Minister of Education and Culture (Mendikbud), Nadiem Anwar Makarim. "Freedom to learn is the freedom of thought. Furthermore, especially the essence of freedom of thought, this must be in the teacher first. Without occur in teachers, are unlikely to occur the student," said Nadiem in discussions National Standard of Education, at Century Park, Central Jakarta on Friday, December 13, 2019. The essence of freedom of thought, it must be preceded by the teachers before they teach the students. He also mentioned, in the competence of teachers at any level, without any process of translation from basic competence and the existing curriculum. There will never be learning that occurs.

MOEC launched the freedom to learn policy is intended for higher education titled "Kampus Merdeka." The launch of the Kampus Merdeka program is delivered by Mendikbud to the media in higher education (HE) policy coordination meeting at Building D Kemendikbud office, Jakarta, Friday (24/01/2020). "This is an early stage to shed the shackles make it easier to move. We still have not touched the aspects of quality. There will be some matrix that will be used to help the college achieve its goals," he said. Mendikbud has also explained, "The Kampus Merdeka Policy is a continuation of the concept of Freedom to learn. The execution most likely to take place soon, just changes the regulation of the minister, not to change government regulation or law.

Kampus Merdeka lately becomes the center of attention for the education circle in Indonesia. How not, since it has been launched, it has been able to hypnotize the entire 
educational community in Indonesia. The Kampus Merdeka is believed to be an attempt to free the education system that is more supportive of students and lecturers, in achieving quality learning meaningful to face the disruption of the current era.

Indeed, freedom is the right of all peoples, including the right of all living systems (education) that have been outlined in the Preamble to the Constitution of 1945, so that the context of freedom is not foreign to us, but free in the sense of a more comprehensive perhaps we still can not reach. Through Kampus Merdeka, it is possible that a more thorough freedom interpretation will be realized by concrete efforts towards the entire Indonesian nation to achieve prosperity, intellectual life and maintain world order. This is in line with the thinking of renowned philosopher Paulo Freire. Freire said that "no pedagogy which is truly liberating can remain distant from the oppressed by treating them as unfortunates and by presenting for their emulation models from among the oppressors. The oppressed must be their example in the struggle for their redemption" (Freire, 1970).

Freire believed education could not be divorced from politics; the act of teaching and learning are considered political acts in and of themselves. Freire defined this connection as the central tenet of critical pedagogy. Teachers and students must be made aware of the politics that surround education. The way students are taught and what they are taught serves a political agenda. Teachers, themselves, have political notions they bring into the classroom (Kincheloe, 2008). Freire believed that "education makes sense because women and men learn that through learning they can make and remake themselves because women and men can take responsibility for themselves as beings capable of knowing - of knowing that they know and knowing that they don't" (Freire, 2004).

Therefore, this paper presents the author's views on "Kampus Merdeka" which was promoted by the MOEC, Indonesia. Also, the author will present the Concept of "Kampus Merdeka" in Accordance with Paulo Freire's Critical Pedagogy.

\section{POINT OF VIEW AND DISCUSSION}

\section{The Philosophy of "Kampus Merdeka"}

\section{What is Merdeka Belajar - Kampus Merdeka?}

"Giving the freedom and autonomy to educational institutions, and freedom of bureaucratization, lectures freed from bureaucracy and students are given the freedom to choose their preferred field" Nadiem Anwar Makarim, Mendikbud, Indonesia.

\section{Why Need Kampus Merdeka?}

To meet the demands, current changes and the need to connect and match with the world of business and industry, and to prepare students in the world of work, universities are required to be able to design and implement innovative learning so students can achieve learning outcomes including aspects of attitudes, knowledge, and skills optimally. The Kampus Merdeka Policy is expected to be the answer to these demands. The Kampus Merdeka is a form of learning in higher education that is autonomous and flexible so that the creation of an innovative learning culture, not limiting, and in accordance with student needs. The Kampus Merdeka Program includes four main policies, namely: the ease of opening new study programs, changes in the accreditation system of higher education, the ease of higher education to become a legal entity, and the right to study three semesters outside the study program. Students are given the freedom to take credit outside the course; three semesters in an average can be taken to study outside the study program in college and or study outside the college. Learning Activities outside college include apprenticeship/work practices, projects in the villages, teaching in schools, student exchange, research, entrepreneurial activity, study/independent projects, and projects that humanitarian projects in which all activities must be guided by lecturers. The Kampus Merdeka is expected to provide a contextual field experience that will increase college 
student competence as a whole and ready to work. The learning process in the Kampus Merdeka is one embodiment of student-centered learning (student-centered learning) is essential. Learning in the Kampus Merdeka provides challenge and opportunity for the development of creativity, capacity, personality, and the students' needs, and develop selfreliance in the search for and discover knowledge through reality and market dynamics such capability requirements, problems real, social interaction, collaboration, selfmanagement, performance demands, targets, and achievements. Through the Kampus Merdeka is expected to respond to the challenges of HE to produce graduates with the development of science and technology and the demands of the business world and the world of industry (Nizam, 2020).

\section{What is the Purpose Kampus Merdeka?}

(1) To encourage the learning process in college more autonomous and flexible; (2) Creating a learning culture that is innovative, not restrictive, and according to the needs of students.

\section{What is the Basic Law of Merdeka Belajar - Kampus Merdeka?}

- New Study Program Opening: (1)Minister of Education and Culture Regulations No. 7 the Year 2020 concerning Establishment, Amendment, Dissolution of State Universities and Establishment, Amendment, Revocation of Licenses Colleges. (2) Minister of Education and Culture Regulations No. 5 the Year 2020 on Accreditation of Study Programs and College.

- Accreditation system: Minister of Education and Culture Regulations No. 5 the Year 2020 on Accreditation of Study Programs and College.

- State Universities Law Firm: (1) Minister of Education and Culture Regulations No. 4 the Year 2020 on the Amendment of State Universities into State Universities Legal Entity. (2) Minister of Education and Culture Regulations No. 6 the Year 2020 concerning Admissions Undergraduate Programs at State Universities.

- Rights Learning Outside the Three Semester Study Program: Minister of Education and Culture Regulations No. 3 the Year 2020 on National Standards of Higher Education.

\section{Who is involved in the Kampus Merdeka?}

- Eligible are students.

- Facilitating that is Lecturer, Instructor, and Educational Staf, Management of Universities, Government Agencies, Agency/institution Research, and Community Service, Business World and the World Industries, Partner College.

- Regulator: The Directorate General of Higher Education the MOEC, Indonesia.

\section{How the Mechanism for Implementing The Kampus Merdeka?}

- Students enroll Internship (choose courses on Study Plan Card system that can be taken in the outer college/internship/outer study program).

- Students following the administrative and academic selection mechanism in accordance with the company/other colleges.

- Students pass the selection conducted by industry/ other study programs.

- Student internship/study in other colleges/other study programs.

- Process assessment is done by the supervisor with supervisor from industry or lecturer from the receiving college or recipient study program.

- Students get the value from college or study program other or industrial and internship certificate.

- Conversion value and recognition of the semester credit unit. 
- Value inputted in study result card the college of origin reports to the Higher Education Database (i.e., PDDikti)

\section{How is the calculation of Semester Credit Unit for Learning Off-Campus?}

Each Semester Credit Unit is defined as "hours of activity," not "hours of teaching." Definition of "activities": Classroom learning, internship, student exchange, village projects, entrepreneurship, research, independent study, and teaching in remote areas. All types of activities chosen must be guided by the lecturer (lecturers are determined by the college). The list of "activities" that can be taken by students (in three semesters off campus) can be selected from (a) a program determined by the government, (b) a program approved by university leaders. Calculation of Semester Credit Unit for off-campus learning is equivalent to 170 (one hundred seventy) minutes per week per semester.

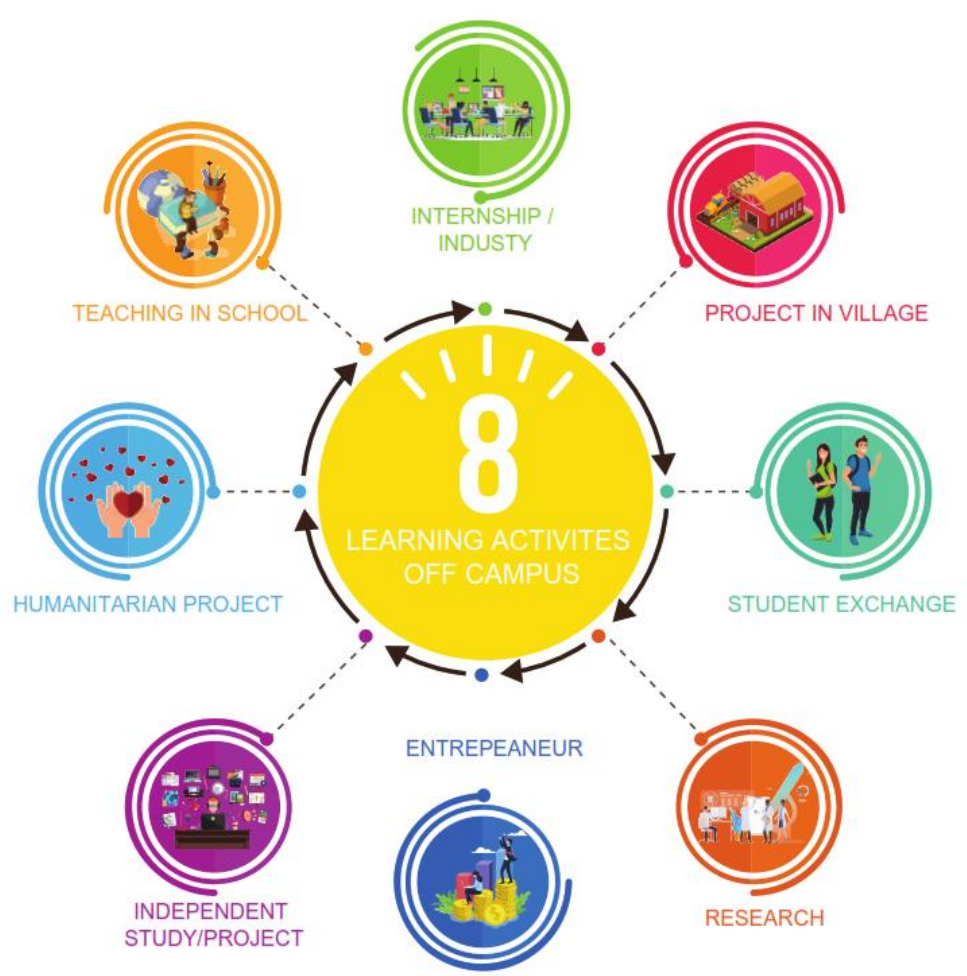

(Adapted: Nizam, 2020)

Figure 1. The concept of 8 off-campus learning activities in "Kampus Merdeka"

"The Kampus Merdeka Policy is a continuation of the concept of freedom to learn," Nadiem Makarim said in HE policy coordination meeting at the office Kemendikbud D Building, Senayan, Jakarta, Friday (24/01/2020). In the fourth, the Kampus Merdeka policy is about giving the right for students to take courses outside the study program and make changes to the definition of Semester Credit Unit (SCU). The weight is given SCU, according to Nadiem, there is a change in the understanding of the SCU. Each SCU interpreted as 'hours of activity,' not 'hours of learning.' Activity here means learning in the classroom.

Figure 1 illustrates there are eight instances of student activities that can be done outside the campus of origin, among others:

- Internship/work practices, college students can participate in a company internship activities, nonprofit foundations, multilateral organizations, government institutions, as well as startups. During the internship, the student required to be supervised by a lecturer or supervisor. The goal is that the theory on campus can be applied in the internship. 
- The project in the village, there is one interesting thing here. Therefore, this event is similar to the Community Service Program. However, college students will be involved in the project in the village. This social project to help people in rural or remote areas in building a people's economy, infrastructure, and more. This activity can be conducted with village officials (village head), Village-Owned Enterprises, cooperatives, or other village organizations.

- Teaching in schools, Undergraduate students can take subjects cross study programs, besides to get their knowledge from campus, students are required to carry out teaching activities at school. This can be done at the elementary, junior high, or high school. Activities carried out for several months, and the school could be in the city or in a remote area. Later, students taking off-campus activities of the Kampus Merdeka program will be facilitated directly by the MOEC.

- Student exchanges, one of the activities outside the campus are attracted by many students. Therefore, students take classes or semesters at universities abroad or domestically. Thus, students can gain additional knowledge and a new atmosphere on other campuses-however, all based on a cooperation agreement that has been arranged by the government. Grades and credits taken in the college beyond will be synchronized by each college.

- Study/research for academic research activities, both social science, and humanities, carried out under the supervision of professors or researchers. This can be done for research institutions such as The Indonesian Institute of Sciences (LIPI) or the National Research and Innovation Agency (BRIN).

- Entrepreneurial activities, college students developed independently entrepreneurial activity must be proven with an explanation/proposal entrepreneurial activity and consumer transaction receipt or slip salaries. For those college students who participate in these activities shall be supervised by a lecturer/teacher.

- Study/independent projects, college students can develop a special project based on social topics and can be done together with other students. Students who join this activity shall also be guided by a lecturer/teacher.

- For those who love social activities, then joined the humanitarian project can be followed by students. Social activities for a foundation or humanitarian organizations must be approved by the college, both at home and abroad. An example of a formal organization that could be approved by Rector is the Indonesian Red Cross, Mercy Corps, and others.

Table 1. The philosophy of 8 off-campus learning activities in "Kampus Merdeka"

\begin{tabular}{|c|c|c|c|}
\hline \multicolumn{4}{|c|}{ Off-Campus Learning activities } \\
\hline \multicolumn{3}{|c|}{ Philosophy } & \multirow{2}{*}{$\begin{array}{c}\text { Responsible } \\
\text { College }\end{array}$} \\
\hline Ontology & Epistemology & Axiology & \\
\hline \multicolumn{4}{|c|}{ Internship/Industrial Practice } \\
\hline $\begin{array}{l}\text { Apprenticeship in a } \\
\text { company, nonprofit } \\
\text { foundations, } \\
\text { multilateral } \\
\text { organizations, } \\
\text { government } \\
\text { institutions, as well as } \\
\text { startups. } \\
\text { Must be guided by a } \\
\text { lecturer or supervisor. }\end{array}$ & $\begin{array}{l}\text { During this time, college } \\
\text { students lack work } \\
\text { experience in } \\
\text { industry/real } \\
\text { professions, so less } \\
\text { ready to work. While } \\
\text { short-term internships } \\
\text { (less than six months) } \\
\text { are not enough to } \\
\text { provide the experience } \\
\text { and industry }\end{array}$ & $\begin{array}{l}\text { The internship } \\
\text { program 1-2 } \\
\text { semesters, provides } \\
\text { sufficient } \\
\text { experience to } \\
\text { students, as well as } \\
\text { the industry get } \\
\text { talents that if } \\
\text { suitable later, can } \\
\text { be directly } \\
\text { recruited, thereby }\end{array}$ & $\begin{array}{l}\text { Prepare the } \\
\text { student's } \\
\text { departure. } \\
\text { Assign a lecturer } \\
\text { who will guide the } \\
\text { students during } \\
\text { the internship } \\
\text { from campus. } \\
\text { - If possible, the } \\
\text { accompanying } \\
\text { lecturer visits the }\end{array}$ \\
\hline
\end{tabular}




\begin{tabular}{|c|c|c|c|}
\hline \multicolumn{4}{|c|}{ Off-Campus Learning activities } \\
\hline & Philosophy & & Responsible \\
\hline Ontology & Epistemology & Axiology & College \\
\hline & $\begin{array}{l}\text { competence for } \\
\text { students. Companies } \\
\text { that accept interns also } \\
\text { stated internship in a } \\
\text { short time is not useful, } \\
\text { even interfere with the } \\
\text { activity in the industry. }\end{array}$ & $\begin{array}{l}\text { reducing the cost of } \\
\text { recruitment and } \\
\text { initial training. } \\
\text { College students } \\
\text { who are already } \\
\text { familiar with the } \\
\text { work site will be } \\
\text { ready to enter the } \\
\text { world of work and } \\
\text { career. }\end{array}$ & $\begin{array}{l}\text { internship for } \\
\text { monitoring and } \\
\text { evaluation. } \\
\text { The accompanying } \\
\text { lecturers together } \\
\text { supervisor } \\
\text { assesses student } \\
\text { achievement } \\
\text { during the } \\
\text { internship. }\end{array}$ \\
\hline
\end{tabular}

\begin{tabular}{l}
\hline Projects In the village \\
\hline Social project to \\
help people in \\
rural or remote \\
areas in \\
building a \\
people's \\
economy, \\
infrastructure, \\
and more. This \\
activity can be \\
conducted with \\
village officials \\
(village head), \\
Village-Owned \\
Enterprises, \\
cooperatives, or \\
other village \\
organizations. \\
Must be guided \\
by a lecturer or \\
instructor
\end{tabular}

\section{The Government,} through the Ministry of Village, Development of Disadvantaged Regions, and Transmigration and Transmigration 1 billion /village to some 78 thousand villages in Indonesia. Twentyseven thousand villages that receive financial assistance are underdeveloped villages. Meanwhile, Village human resources do not yet have the ability to plan development with such large funding facilities.

Therefore, the effectiveness of the use of village funds to drive economic growth still needs to be improved; one of them is through college students who can become human resources which more empower village funds.
- College student attendance for 6-12 months can assist the planning of programs, ranging from the study of the potential village, problems, and challenges of rural construction, prioritizing the construction, design programs, design of infrastructure, community empowerment, management of Village-Owned Enterprises, supervision of construction, to monitoring and evaluation.

- Provide professional experience in the field of community construction and empower the public to prepare college students as an optimal generation.

- Provides an opportunity to develop college student interest in science and with the final outcome in the form of written
- Cooperating with the Ministry of Rural and Disadvantaged Regions Development, and Transmigration, as well as in the implementation of the program of MOEC project in the village or cooperates directly with local governments for the implementation of the project program in the village.

- Manage enrollment and placement of college students into the destination country.

- Assign the accompanying lecturers who will guide the college students during the internship from campus.

- If possible accompanying lecturers conduct on-site visits for monitoring and evaluation apprentice. 


\begin{tabular}{ll}
\hline \multicolumn{1}{c}{ Off-Campus Learning activities } \\
\hline Philosophy & \multicolumn{1}{c}{ Axiology } \\
\hline Entology & works, audio- \\
& visual, and the \\
& form of the work of \\
& other college \\
& students' final \\
& report.
\end{tabular}

Student exchange

Take classes or

semesters at

universities abroad

or domestically

based on a

cooperation

agreement that has

been arranged by

the Government.

Grades and credits

taken in the college

beyond will be

synchronized by

each college.
Currently, the exchange

of students with full

credit transfer has been

done with partners

overseas universities,

but the credit system

transfers made between

universities in the

country itself is still very

few. Student exchange

was organized to form

some of the attitudes of

college students are

contained in the

Minister of Culture and

Culture Regulations No.

3 the Year 2020, that

respect cultural

diversity, views,

religion, and

confidence, as well as

opinion or the original

findings of any other

person, as well as

cooperate and social

sensitivity and concern

for the community and

the environment.

\section{Responsible}

College

- Send college

students.

- The accompanying lecturers together with the supervisor in the village of assessing projects done by the college students.

- Learning across campus (domestic and foreign), living together with a family on another campus destination, college student insight about Unity in Diversity will be strong, crosscultural and ethnic fraternity will be stronger.

- Organize the transfer of knowledge to cover educational disparities both between universities in the country, as well as the condition of higher education in the country with other countries.
- Cooperates with universities in the country and abroad or with a scientific consortium for the implementation of a credit transfer can be followed by college students.

- Colleges may allocate the quotas for inbound students or some students who do outbound (reciprocal).

- Organize the exchange student selection system that meets principle justice for college students.

- Control in the organization of student exchange.

- Assess and evaluate the results of student exchange for later recognition of the credits students.

\section{Entrepreneur}

Students develop entrepreneurial activities independently proven with an explanation or proposal entrepreneurial activity and consumer transaction receipt or slip salaries. Must be

\section{Based on the Global}

Entrepreneurship Index

(GEI) 2018, Indonesia

has a score of $21 \%$ of

entrepreneurs from the

fields of employment, or rank 94 of the 137

countries surveyed.

Meanwhile, according to research darn IDN
- $\quad$ Provide college students have the interest of entrepreneurs to develop their business more freely.

- To deal with the problem of unemployment,
- $\quad$ Provide a budding business incubation center for students.

- Provide an integrated entrepreneurial learning system with direct practice. 


\begin{tabular}{|c|c|c|c|}
\hline \multicolumn{4}{|c|}{ Off-Campus Learning activities } \\
\hline & Philosophy & & Responsible \\
\hline Ontology & Epistemology & Axiology & College \\
\hline $\begin{array}{l}\text { guided by a lecturer } \\
\text { or teacher. }\end{array}$ & $\begin{array}{l}\text { Research Institute in } \\
2019,69.1 \% \text { of the } \\
\text { millennial in Indonesia } \\
\text { has an interest in } \\
\text { entrepreneurship. } \\
\text { Unfortunately, the } \\
\text { potential } \\
\text { entrepreneurship for the } \\
\text { millennial generation } \\
\text { not yet be managed } \\
\text { properly during this } \\
\text { time. The Kampus } \\
\text { Merdeka Policy is trying } \\
\text { to develop student } \\
\text { interest in } \\
\text { entrepreneurship } \\
\text { programs off-campus } \\
\text { learning activities. }\end{array}$ & $\begin{array}{l}\text { which results } \\
\text { from the } \\
\text { intellectual } \\
\text { unemployment } \\
\text { among scholars. }\end{array}$ & $\begin{array}{l}\text { Provide training, } \\
\text { mentoring, and } \\
\text { guidance of } \\
\text { lecturer and } \\
\text { experts in } \\
\text { entrepreneurship. } \\
\text { Connects business } \\
\text { of college students } \\
\text { with the market. } \\
\text { Provide } \\
\text { accompanying } \\
\text { lecturers to college } \\
\text { students. } \\
\text { Provide } \\
\text { equalization to the } \\
\text { entrepreneurial } \\
\text { activity into SCU } \\
\text { earned by college } \\
\text { students. }\end{array}$ \\
\hline
\end{tabular}

\begin{tabular}{l} 
Studies/Independent P \\
\hline College students \\
can develop a \\
special project based \\
on social topics and \\
can be done \\
together with other \\
students. Must be \\
guided by a lecturer \\
or teacher
\end{tabular}

\section{Studies/Independent Project}

can develop a special project based on social topics and can be done together with other guided by a lecturer or teacher
Many college students who have a passion for creating great works that competed at the international level or the work from an innovative idea. Ideally, an independent study carried out for a complement of the curriculum that has been taken by the college students. College or faculty can also make independent studies to complete topics not included in the schedule of lectures, but still available in the syllabus of the study program or faculty.
- $\quad$ Embodies the idea of students in developing innovative products that become the ideas.

- Organize research and development (R\&D) based education.

- Improve student achievement in the national and international arena.
- Providing accompanying lecturers for independent projects requested by students.

- Facilitating the formation of an independent project team consisting of students across study programs and across faculties.

- Set academic considerations for the feasibility of the proposed independent project.

- Provide accompanying lecturers according to an expert from the proposed independent project topic.

- Organize guidance, mentoring and training in the 


\begin{tabular}{|c|c|c|c|}
\hline \multicolumn{4}{|c|}{ Off-Campus Learning activities } \\
\hline \multicolumn{3}{|c|}{ Philosophy } & Responsible \\
\hline Ontology & Epistemology & Axiology & College \\
\hline & & & $\begin{array}{l}\text { process of } \\
\text { independent } \\
\text { projects run by } \\
\text { students. }\end{array}$ \\
\hline
\end{tabular}

\begin{tabular}{l}
\hline Humanitarian projects \\
Students develop \\
entrepreneurial \\
activities that are \\
independently proven \\
by an explanation or \\
entrepreneurial \\
proposal and receipt \\
of consumer \\
transactions or salary \\
slips. Must be guided \\
by a lecturer or \\
teacher
\end{tabular}

Based on a report from UNOCHA found on the pages of the Indonesian Ministry of Foreign

Affairs, the global humanitarian crisis that occurred in various parts of the world throughout 2017 was one of the worst since World War II. Nearly 140 million people have been affected by the crisis or doubled compared to 10 years ago. Many international institutions (UNESCO, UNICEF, WHO, etc.) have conducted indepth studies and made pilot development projects in Indonesia and other developing countries. Students with young enthusiasm, competence, knowledge, and interests can become "foot soldiers" who replicate the humanitarian project.
- It makes plenary students who uphold humanity's values in carrying out tasks based on religion, morals, and ethics

- Train students' social sensitivity to explore existing problems to be solved in accordance with their respective interests and expertise.
- Work closely with the MOEC as well as national and international humanitarian organizations to organize programs based on national and international agendas (such as MDGs, health, population, etc.)

- In the event of an emergency humanitarian disaster, the university can directly assign students to work on humanitarian projects.

- Organize selection for humanitarian projects.

- Ensure that humanitarian projects run by students are carried out in accordance with the main objectives.

- Provide accompanying lecturers for monitoring and evaluating humanitarian projects conducted by students.

- Carry out humanitarian activities for equal hours to be recognized as credit. 


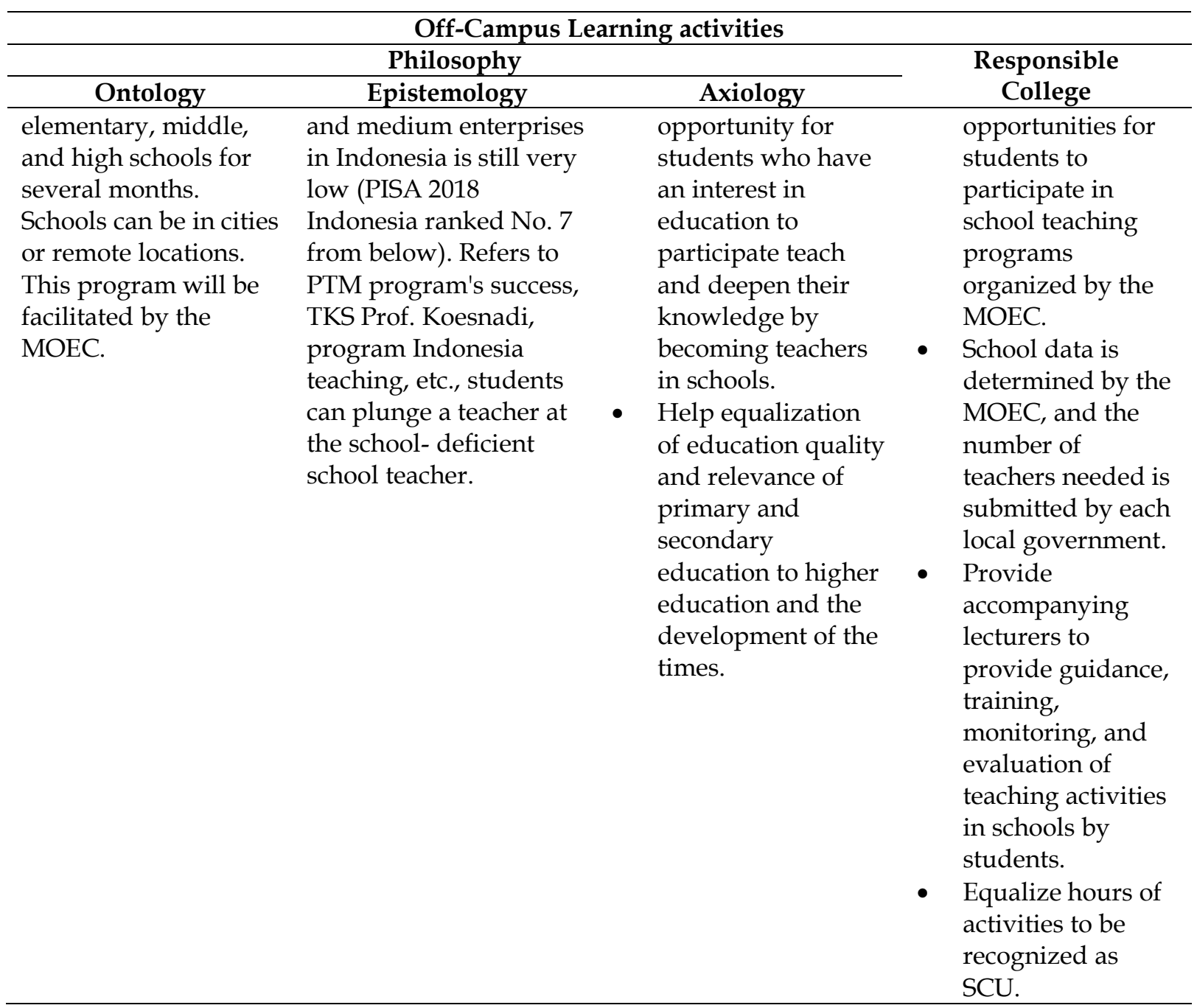

\section{Paulo Freire's Critical Pedagogy}

Paulo Freire contributed a philosophy of education that blended classical approaches stemming from Plato and modern Marxist, post-Marxist, and anti-colonialist thinkers. His Pedagogy of the Oppressed (1970) can be read as an extension of, or reply to, Frantz Fanon's The Wretched of the Earth (1961), which emphasized the need to provide native populations with an education which was simultaneously new and modern, rather than traditional, and anti-colonial-not simply an extension of the colonizing culture.

Freire's thinking about education is more like normative instruction (guidance) about education. It means in the form of guidance to be a true teacher and student in the sense of knowing his position and responsibilities, how to read or learn productively, addressing the socio-cultural and socio-political environment critically and trying to play well in the environment and system where he must continue to make changes. The substance of Freire's thought lies in his view of man, about his world, which is then transformed into an education world that produces alternative educational models offered, namely educational models that bind to the freedom model. Therefore, it seems futile to understand Freire's thinking, as stated in many of his works that are scattered about it, without understanding the philosophy of education. A brief review of Paulo Freire's educational philosophy cannot illustrate the completeness and depth of ideas, and perhaps it shows that Freire's ideas are not entirely new ideas (Freire himself humbly acknowledged that his idea was the accumulation of ideas of predecessor thinkers: Sartre, Althusser, Mounier, Ortega Y. Gasset, Unamuno, Martin Luther King Jr. and so on). However, one thing is certain is that Freire 
must show all the great ideas that are unique and renewed, with a broad set of action applications, most mastered as sector experts, a professor of History and Philosophy of Education at the University of Recife, Brazil (Siswanto, 2007).

If someone has been able to reach the level of critical awareness of reality, that person starts to enter the process of understanding and not the process of memorization. People who understand are not those who memorize, because they declare themselves or something based on a "system of consciousness," whereas those who memorize only express themselves or something mechanically without realizing what he is saying, from which he has received the memorization he expressed it and for what he restated at that time (Freire, 1985; Siswanto, 2007).

\section{Criticism of the "banking model" of education}

In terms of pedagogy, Freire is best known for his attack on what he called the "banking" concept of education, in which students are viewed as empty accounts to be filled by teachers. He notes that "it transforms students into receiving objects and attempts to control thinking and action, leading men and women to adjust to the world, inhibiting their creative power" (Freire, 1970).

John Dewey was also strongly critical of the transmission of mere facts as the goal of education. Dewey often described education as a mechanism for social change, stating that "education is a regulation of the process of coming to share in the social consciousness; and that the adjustment of individual activity on the basis of this social consciousness is the only sure method of social reconstruction" (Dewey, 1897). Freire's work revived this view and placed it in context with contemporary theories and practices of education, laying the foundation for what would later be termed critical pedagogy.

\section{'Kampus Merdeka,' Paulo Freire' Critical Pedagogy and Our Point of View}

Actually, the concept of the Kampus Merdeka is the development of the thoughts of Paulo Freire, an architect in the field of education, who also transformed into the world. The essence of Freire's view applies in humans and the world, which later became the world of education. The Freire educational model offered is a freedom educational model. Freedom, in this case, means a transformation in an interconnected and complex system of reality. In addition, it reforms several individuals to reduce the negative consequences of their behavior.

The most decisive first step in efforts to release education is an inherent awareness process. This is the core process or the essence of the whole education process itself. To achieve this, descriptive education habits are expected to shift to dialogic-transformative education so that education is not seen as a binding education. Education is expected to produce changes in students, both in the quality of thinking, personal quality, social quality, quality of independence, and the quality of community services. Richard Shaull, drawing on Paulo Freire said that "there is no such thing as a neutral education process. Education either functions as an instrument which is used to facilitate the integration of generations into the logic of the present system and bring about conformity to it, or it becomes the 'practice of freedom,' the means by which men and women deal critically with reality and discover how to participate in the transformation of their world" (Mayo, 1990).

Table 2. Point of view "Kampus Merdeka Policy and Paulo Freire' Critical Pedagogy"

No.

The Kampus Merdeka Policy

Paulo Freire' Critical Pedagogy

$1 \quad$ Minister of Education and Culture Regulation No. 3 of 2020 concerning National Standards for Higher Education: Higher Education must give

Freire believed that "education makes 
students the right to voluntarily (can be taken or not): Can take credit outside of college as much as two semesters (equivalent) up to 40 credits. Plus, they can take credit in various study programs in the same college for one semester (equivalent to 20 credits).

Therefore, Higher Education must facilitate the implementation of the fulfillment of part of the time and learning burden of students in the learning process with alternative options:

The entire learning process in the study program is carried out in college in accordance with the period and student learning load; The learning process in the study program to meet part of the learning period and load and provide opportunities for students to take the remainder by following the learning process outside the study program and outside the college.

In other words, the credit that must be taken in the original study program is five semesters of the total semester that must be run (does not apply to the Health study program).

2 The university accreditation system in the Kampus Merdeka program, this program is an automatic re-accreditation for all rankings and is voluntary for universities and study programs that are ready to rise in rank. The accreditation that has been established by the National Accreditation Board for Higher Education (BAN-PT) remains in force for five years but will be renewed automatically. Submission of the reaccreditation College and Study Program limits the fastest to two years after getting the last accreditation. For college accredited $B$ and $C$ can apply for improvement "Later, Accreditation A will be given to college that has succeeded in getting international accreditation. The list of accredited International accreditation will be determined by the Minister," Nadiem added.

Evaluation of accreditation will be carried out by BAN-PT if the quality deterioration is found, including public complaints accompanied by concrete evidence, as well as a sharp decrease in the number of new students who register and graduate from study programs or college.

3 The right to three semesters of study outside the Kampus Merdeka study program and give students the right to take courses outside the study program and make changes to the definition of Semester Credit Units (SCU). "Higher education will give students the right to volunteer, so students must take or not credit off-campus for two semesters or equal to 40 SCU", Nadiem said. He continued, "In addition, students can also take credit in other study programs on-campus as much as one semester of the total semester that must be taken. This does not apply to health studies programs." Nadiem is currently assessing credit weights for learning outside of class activities is very small and does not encourage students to seek new experiences, especially on many campuses, student exchanges, or work practices that actually delay student graduation. Furthermore, the Minister of Education explained the change in the understanding of the SCU. Each SCU is defined as an 'activity hour,' not a 'study hour.' Activities here means learning in the classroom, internships, or practice in the workplace in an industry or organization, student exchange, community service, entrepreneurship, research, independent learning, and teaching in remote areas. "Every student selected activity must be guided by a lecturer who is determined by the campus. The list of activities that can be taken by students can be selected from programs determined by the government and/or sense because women and men learn that through learning they can make and remake themselves because women and men are able to take responsibility for themselves as beings capable of knowing - of knowing that they know and knowing that they don't" (Freire, 2004)

Oppressors must be willing to rethink their way of life and to examine their own role in oppression if true freedom is to occur: "those who authentically commit themselves to the people must re-examine themselves constantly"(Freire, 1970)

In terms of pedagogy, Freire is best known for his attack on what he called the "banking" concept of education, in which students are viewed as empty accounts to be filled by teachers. He notes that "it transforms students into receiving objects and attempts to control thinking and action, leading men and women to adjust to the world, inhibiting their creative power" 
No.

\section{Paulo Freire' Critical Pedagogy}

programs approved by the rector," said the Minister of Education.

(Freire, 1970).

$4 \quad$ The opening of new study programs from the Kampus Merdeka Program gives autonomy to State and Private Universities to conduct the opening or establishment of a recent study program. Autonomy is granted if public and private universities have been accredited A and B, and have worked with organizations and / or universities that are included in the QS 100 Top World Universities. Exceptions apply to health and education study programs. Added by the Minister of Education, "All new study programs will automatically get $C$ accreditation." Furthermore, the Minister of Education explained that collaboration with organizations would include curriculum development, work practices or internships, and work placements for students. Then the MOEC will work closely with universities and study program partners to conduct surveillance. "Tracer studies must be conducted every year, Universities are required to ensure this is implemented," said Minister of Education and Culture Nadiem

5 Ease into PTN-BH Kampus Merdeka Policy, and third relates to the freedom for the state universities of Public Service Agency (BLU) and Work Unit to be State Legal Entity (PTN BH). MOEC will facilitate PTN BLU requirements and Work Unit to be bound PTN BH without accreditation status.

No pedagogy,
which is truly
liberating, can
remain distant from
the oppressed by
treating them as
unfortunates and by
presenting for their
emulation models
from among the
oppressors. The
oppressed must be
their own example
in the struggle for
their redemption
(Freire, 1970).
Education is a
regulation of the
process of coming
to share in the social
consciousness; and
that the adjustment
of individual
activity on the basis
of this social
consciousness is the
only sure method of
social
reconstruction
(Freire, 1970)

No pedagogy, which is truly liberating, can remain distant from the oppressed by treating them as unfortunates and by presenting for their from among the oppressors. The oppressed must be their own example in the struggle for their redemption (Freire, 1970).

Education is a regulation of the process of coming to share in the social consciousness; and that the adjustment activity on the basis of this social consciousness is the only sure method of reconstruction (Freire, 197

The launching of the Kampus Merdeka program was conveyed by Minister of Education and Culture Nadiem delivered to the media in a higher education policy coordination meeting at the Education and Culture Building, Jakarta, Friday (1/24/2020). "This is the initial stage to release shackles to make it easier to move. We still have not touched the quality aspect. There will be several matrices that will be used to help universities achieve their goals". Nadiem explained, "The Kampus Merdeka policy is a continuation of the Merdeka Belajar concept. Its execution is likely to happen soon, only changing ministerial regulations, not to changing government regulations or laws." In Pedagogy of the Oppressed, Freire, reprising the oppressors-Oppressed distinction, the distinction Applies to education, championing that education should allow the Oppressed to regain Reviews their sense of humanity, in turn Overcoming Reviews their condition. Nevertheless, he acknowledges that for this to occur, the Oppressed individual must play a role in their freedom.

Freire described conscientientizaco as a process to become a complete human being. This development process can be divided into three phases; magical awareness, naive (naival consciousness), and critical (critical consciousness). Magical consciousness is public awareness that is unable to see one factor to another, for example, poor people who cannot see their poverty with a political and cultural system. Magical consciousness looks more at 
factors outside of humans as causes and powerlessness. Naival consciousness, a condition that is categorized in this awareness, is to see the human aspect as the root cause of community problems. While critical consciousness sees more aspects and structures as sources of problems. The structural review avoids "blaming the victims" and analyzes it further. Furthermore, it was also regarding the critical structure and social, political, cultural economy and its influence on the state of society (Siswanto, 2007; Topatimasang et al., 2010).

This awareness process is a process that is internal and psychological, and changes to individuals who care about their world, or also the socio-political aspects of their world. It must be emphasized that internal change has significant external manifestations. Does individual behavior change as a result of changing ways of thinking. If this level of awareness can be measured, then the question becomes important, which remains unanswered.14 Consciousness in general, and Conscientientizaco, in particular, discusses changes in human relations that will restore human debauchery. Conscientientizaco is not a technique for transferring information, or even for skills training, but it is a dialogical process that unites individuals to solve their existential problems. Conscientientizaco has the duty of freedom, and freedom means the creation of new norms, rules, procedures, and policies. Freedom means the transformation of interrelated and complex systems, and individual reforms to reduce the negative consequences of their behavior (Freire, 1975; Siswanto, 2007).

Freedom can only be done in the real sense if a person is truly aware of the reality of himself and the world around him will never be able to recognize what he really wants to do, will never be able to understand what he really wants to achieve. So it is impossible to understand someone that he must be able to, and basically can understand the reality of himself and the world around him before he fully realizes that ability is a natural human tendency and that understanding itself is important and possible for him (Freire, 1985; Siswanto, 2007).

In other words, the most decisive first step in the educational effort for Freire's release which is an ongoing process, a "beginning," which always "starts and starts again," then the process of awareness will always be there, and it is a process that is partly (inherently) in the whole process of education itself. So the process of awareness is the core process or essence of the educational process itself. A person's world of awareness cannot be stopped, stagnated, he must always continue to process, develop and expand, from one stage to the next, from the level of "naive awareness," to the level of "critical awareness," to finally reach the highest and deepest level of consciousness, "the consent of the consciousness" (Freire, 1985; Siswanto, 2007). Those who are oppressed must free and free themselves from in human oppression, while at the same time free the oppressors from the prison of conscience who are not honestly oppressing (Belliappa, 2020). At present, the post-2015 sustainable development agenda, freedom of Education, lies in the idea of a new humanism (Marope, 2017).

The Kampus Merdeka policy package was the first step in a series of policies for tertiary institutions. It carries four policies within the scope of tertiary institutions (i.e., numbers 2-5 in Table 3). According to the authors' view, in general, 4 Kampus Merdeka policies are relevant to Paulo Freire's view. General views from the authors of the Kampus Merdeka are:

- The campus in Indonesia should immediately carry out the mapping and revitalization of the curriculum to adopt the idea of Kampus Merdeka.

- Kampus Merdeka is a creative idea of the MOEC. Is Kampus Merdeka, including innovative ideas? To answer this question needs to be at least one year. We wait for concrete evidence of implementation of this Kampus Merdeka can be an alternative solution proven effective in addressing the problem of education and culture in Indonesia. 
- Implementation of Kampus Merdeka requires a strong internal HR campus (Management, Human Resources, and Finance). These three aspects become the basis that will make the campus will run a solid educational mechanism. There is already plenty of evidence when one aspect of the three foundations is not solid; what happens? A lot of manipulation happened to cover up the low quality of the campus.

- When the Kampus Merdeka can be implemented "good" by tertiary institutions, tertiary institutions will benefit from the 8 Kampus Merdeka programs, because once graduates have good competence, the campus will be increasingly trusted by the business world. For the business world and society in Indonesia also has the advantage because the program is assisted by an internship.

- When Kampus Merdeka can be realized, it is not impossible that Indonesia will become a country that has competent and superior human resources. Why? Indonesia already has extraordinary natural resources, but human resources have not been able to maximize the welfare and progress of the Indonesian people.

Prof. Dr. Maskuri Bakri (jawapos.com) added that besides that perspective from Paulo Freire also emphasized that education as a practice for freedom. The educational model offered by Paulo Freire is an educational model for freedom. In this case, it means a transformation in an interconnected and complex system of reality. In addition, it reforms several individuals to reduce the negative consequences of their behavior. The most decisive first step in the freedom education effort is the inherent awareness process. This is the core process or nature of the entire education process itself. To achieve this, the habit of descriptive education is expected to shift to dialogic-transformative education so that education is not seen as binding education. Education is expected to produce changes in students, both in the quality of thinking, personal quality, social quality, quality of independence, and the quality of society.

However, how good the MOEC's policies are, if they do not pay attention to the various instruments and the involvement of relevant stakeholders that support, implementation will only lead to new problems. According to Prof. Dr. Maskuri Bakri (jawapos.com), there are five important things that need attention.

- First, all partners in education for the Advanced Indonesian Cabinet must support and make linear regulations regarding the MOEC.

- Second, financial support for the implementation of education in state and private universities must be balanced.

- Third, internationalization of education without reducing national character education. Character education must also be given enough space.

- Fifth, the time for implementing the policy must be appropriate, accompanied by clear, concrete, and measurable technical guidelines. In addition, policy socialization must be fast and equitable so that all stakeholders participate in welcoming the success of this new, more promising education policy.

The author himself positively welcomes the creative ideas of the young and innovative Minister Nadiem (e.g., CEO Gojek). Indeed, nothing is perfect in this world. But we must be able to take positive effects to minimize the negative effects of the idea of the Kampus Merdeka. In closing, let us succeed and oversee the Kampus Merdeka policy for the progress and prosperity of the people of Indonesia. To conclude this article, the authors would like to quote the sentence Paulo Freire in the book Education the Practice of Freedom, who wrote: "It is up to history and now for each assessment to determine it." 


\section{CONCLUSION}

The essence of the Kampus Merdeka is freedom and autonomy for educational institutions, and freedom from bureaucracy, lecturers are given freedom from bureaucracy, and students are given the freedom to choose their preferred fields. Kampus Merdeka is believed to be an attempt to free the education system that is more supportive of students and lecturers, in achieving quality learning meaningful to face the disruption of the current era. The concept of the Kampus Merdeka is the development of the thoughts of Paulo Freire, an architect in the field of education, who also transformed into the world. The essence of Freire's view applies in humans and the world, which later became the world of education. The Freire educational model offered is a freedom educational model. Freedom, in this case, means a transformation in an interconnected and complex system of reality. In addition, it reforms several individuals to reduce the negative consequences of their behavior. The most decisive first step in the freedom education effort is the inherent awareness process. This is the core process or nature of the entire education process itself. To achieve this, the habit of descriptive education is expected to shift to dialogic-transformative education so that education is not seen as binding education. Education is expected to produce changes in students, both in the quality of thinking, personal quality, social quality, quality of independence, and the quality of society. The Kampus Merdeka policy package was the first step in a series of policies for tertiary institutions. It carries four policies within the scope of tertiary institutions (i.e., numbers 2-5 in Table 3). According to the author's view, in general, four the Kampus Merdeka policy is relevant to Paulo Freire's view.

\section{REFERENCES}

Belliappa, J.L. (2020). Extending feminist pedagogy in conferences: Inspiration from theatre of the oppressed. Gender and Education, 32(1), 101-114.

Dewey, J. (1897). My pedagogic creed. New York, NY: E.L. Kellogg \& co.

Fanon, F. (1961). The wretched of the earth. France: Grove Press.

Freire, P. (1970). Pedagogy of the oppressed. New York, NY: Continuum.

Freire, P. (1975). Conscientization. Geneva: World Council of Churches.

Freire, P. (1985). The politics of education: Culture, power, and liberation. South Hadley, Mass., Bergin \& Garvey.

Freire, P. (2004). Pedagogy of indignation. Colorado Boulder: Paradigm.

Jawapos.com Retrieved from https://www.jawapos.com/opini/27/01/2020/freirekampus-merdeka-dan-nadiem/

Kincheloe, J.L. (2008). Critical pedagogy primer. New York: Peter Lang.

Marope, P.T. M. (2017). Education: The key to development. Prospects, 47, 305-307.

Mayo, P. (1999). Gramsci, Freire, and adult education: Possibilities for transformative action. London: Zed Books.

Nizam, (2020). Panduan merdeka belajar kampus merdeka. Jakarta: Direktorat Jenderal Pendidikan Tinggi Kemendikbud RI.

Permendikbud Nomor 3 Tahun 2020 tentang Standar Nasional Pendidikan Tinggi.

Permendikbud Nomor 4 Tahun 2020 tentang Perubahan Perguruan Tinggi Negeri menjadi Perguruan Tinggi Negeri Badan Hukum. Kemendikbud: Jakarta.

Permendikbud Nomor 5 Tahun 2020 tentang Akreditasi Program Studi dan Perguruan Tinggi. Kemendikbud: Jakarta.

Permendikbud Nomor 6 Tahun 2020 tentang Penerimaan Mahasiswa Baru Program Sarjana pada Perguruan Tinggi Negeri. Kemendikbud: Jakarta.

Permendikbud Nomor 7 Tahun 2020 tentang Pendirian, Perubahan, Pembubaran Perguruan Tinggi Negeri, dan Pendirian, Perubahan, Pencabutan Izin Perguruan Tinggi Swasta. Kemendikbud: Jakarta. 
Siswanto, (2007). Pendidikan sebagai paradigma pembebasan (Telaah filsafat pendidikan Paulo Freire). Tadris, 2(2), 250-263

Topatimasang, R., Rahardjo, T., \& Fakih, M. (2010). Pendidikan populer membangun kesadaran kritis. Yogyakarta: INSISTPress.

\section{*Corresponding Author:}

Binar Kurnia Prahani

State University of Surabaya, Surabaya, Indonesia

Jl. Ketintang, Surabaya 60231, Indonesia

Email: binarprahani@unesa.ac.id 